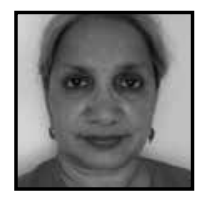

\title{
Teacher Research as Self-Study and Collaborative Activity
}

\author{
Sharada Gade, Umeå University
}

\begin{abstract}
This article highlights two insightful methods for advancing teacher research: practitioner self-study in relation to a range of texts, with which to examine one's educational landscape; and classroom interventions conceived as a Vygotskian activity, via teacher-researcher collaboration. Both approaches allow teachers and collaborating researchers to share individual expertise across institutional boundaries and engage in creative local action.
\end{abstract}

came to educational research after more than a decade of classroom teaching at middle school grades in India. This was followed by doctoral training, after which I had the opportunity to collaborate with teachers and conduct classroom interventions at similar grade levels in Sweden. Such pursuits have allowed me to contribute to three profoundly human endeavours: education, science, and democracy. Along the way, I have striven for innovative means with which to realize human flourishing or the greater Aristotelian good in society. It is by reflecting on the pursuit of such endeavours that I argue in this paper for practitioner self-study and collaborative activity as insightful means with which to advance teacher research.

The theoretical premise in classroom studies I conduct is Vygotskian, guided by three of his many ground-breaking arguments. First is his contention that any educational process is one in which a child is able to educate him or herself through his or her own actions, resulting in newer and cultural forms of development. Vygotsky (1997) next recognized the unfolding of development in education to be active at 
three levels: the student, the teacher, and the environment that gets forged between them. In articulating a methodology for studying environments in which a teacher's guidance advances or leads students' development, Vygotsky (1978) finally put forth the concept of activity, which he considered to be both the prerequisite and product — or tool and result_ - of any study. As a unit of analysis that can be thoughtfully deployed to study instruction in actual classrooms, there is an opportunity here to examine students' cultural development beyond mere biological maturation. It is by drawing on my experiences with teaching and research-in addition to adopting the Vygotskian premise of activity - that I ask: "In what ways could practitioner self-study and collaborative activity between teachers and researchers contribute to and advance teacher research?"

I admit that my attention to teacher research has come as a result of my interests in creating classroom environments, in which students could educate themselves via their own actions. This was the case in my years as a teacher and researcher. While my own schooling took place in competitive environments where students were sorted by various criteria and ranked, I came to teach at a school that lay emphasis on students cooperating with one another and teachers striving to make learning fun. By not having to restrict learning to textbooks or test scores, my school provided me with the space needed to experiment with my teaching and engage my intellectual curiosity with regard to education at large. In line with my training as an experimental physicist, I proceeded scientifically to inquire, observe, look for data, report, and reflect on ways in which one could sustain classroom teaching-learning in creative ways (Gade, 2004). In the absence of structured professional development programs-apart from an occasional workshop-I pursued my interests with passion, reading widely and encountering the wealth of perspectives with which schooling and education are conceived in different intellectual traditions. Such engagement contributed to my self-study as a teacher and continues to this day as I collaborate with teachers in their ongoing classrooms. Clandinin and Connelly (2007) articulate practitioner self-study as focused reflections on thoughts and actions in various educational landscapes. Such studies contribute to professional knowledge by transforming personal practical knowledge of practitioners into social, cultural, and institutional narratives. In finding resonance with experiences of other teachers and researchers, such knowledge has the highest potential of improving education. Given my experiences with teaching mathematics and science in different contexts and research, I now turn to self-study in relation to my reading of a selection of texts that I encountered in my journey. 


\section{Practitioner Self-Study}

The K-10 school ${ }^{2}$ I taught at in Hyderabad, India was founded largely on the teachings of the Indian philosopher Jiddu Krishnamurti. My scientific training and teaching of mathematics and science notwithstanding, I discuss the wider societal debate around the notion of truth in the first of three texts I reflect with and upon as part of my selfstudy. The notion of truth in our national motto in India reads, "Truth alone triumphs." Translated from the Sanskrit Satayameva Jayate and belonging to Ancient Indian Upanishads, I consider this saying to offer direction and purpose to one's everyday activity as well as ethical commitment to what is being pursued.

Interestingly, another text which offers guidance in relation to how truth should be pursued in one's life, is alluded to with greater clarity in the Buddhist saying below:

Believe nothing ...

... merely because you have been told it,

Or because it is traditional,

Or because you yourselves imagined it.

Do not believe what your teacher tells you

Merely out of respect for the teacher.

But whatsoever, after due examination and analysis,

You find to be conducive to the good,

The benefit, the welfare of all beings

That doctrine believe and cling to,

And take as your guide.

Written on a blackboard that lined our school corridor and visible for all to view and ruminate, I consider this saying to not only instill relentless questioning in one's life for truth and knowledge, but also to recognize that any truth being pursued must be conducive to all. With direct bearing on the kind of knowledge that teachers aspire to have, this text specifically advocated that knowledge have social relevance, bearing, and responsibility.

Next, I turn to the nature of truth given expression by Krishnamurti (1929) in his book, Truth Is a Pathless Land. Alluding to intuitive aspects of truth and knowledge, Krishanmurti offered up the following oft-quoted anecdote: 
You may remember the story of how the devil and a friend of his were walking down the street, when they saw ahead of them a man stoop down and pick up something from the ground, look at it, and put it away in his pocket. The friend said to the devil, "What did that man pick up?" "He picked up a piece of Truth," said the devil. "That is a very bad business for you, then," said his friend. "Oh, not at all," the devil replied, "I am going to let him organise it."

The three texts cited above, widely known to many in India, lead me to highlight two aspects that are pertinent to wider societal practices in education. First, the kind of texts I mention are not only world making, but also exemplary of the kinds of texts that schools worldwide often use to initiate students into culturally whetted meanings. Second, it is the lot of school teachers in any cultural milieu to weigh in on such notions with their students, alongside parallel notions of truth in mathematics and science. As a classroom teacher, my own approach had been to engage in dialogue with students and attempt to broaden our horizons in line with Gadamer's rejoinder that the "other" in any conversation may be right (Fairfield, 2010). In parallel with Krishnamurti's pathless approach to truth, Gadamer suggests that personal understanding is not bound to any method, but obtainable by means of accessing social reality in hermeneutic terms. Gadamer's arguments seem conducive to another point that Krishnamurti emphasized: that to live was to be related to one another. It was in line with the latter's writings that the teachers at my school-one in which I taught for more than a decade-attempted to create a culture of relational and dialogic inquiry.

I now turn to examine texts that discuss the nature and pursuit of science, which for me includes mathematics as well. I begin by discussing my encounter with Jacob Bronowski's television series, The Ascent of Man. Through vivid footage and astute commentary, this series chronicles the development of modern-day civilization from its nomadic origins. Watching this series enriched my perception of science in three specific ways: that the practice of science its teaching included, was closely coupled with human values; that as a human enterprise science was driven also by an artistic and forward-looking imagination; and, lastly, that overall progress in science had an inbuilt historicity. Upon reading Bronowski's book (1973) of the same title, I began to consciously embed my teaching with explicit references to its wider societal practice, bring to discussion underlying dimensions of human values, and have students appreciate historical links within its various topics. Imparting such a stance within instruction allowed for overcoming the risk of treating science as separate findings that could be glossed over in textbook chapters. In parallel with the Buddhist dictum of questioning, Bronowski (1965) posits "Is that so?" as the central question asked when science sought truth and made sense of the world. Moreover, Bronowski added 
that one needed to allow for dissent and have respect for another person's point of view. In tune with a dialogical emphasis practiced at school and as also advocated by Gadamer, Bronowski highlights the democratic character of science. Having bearing not only on classroom teaching, but also on vital stakeholder voice while conducting classroom research, Bronowski (1965) distinguishes between the findings of science from its societal practice:

Science is not a mechanism but a human progress, and not a set of findings but a search for them. Those who think science is ethically neutral confuse the findings of science, which are, with the activity of science, which is not. (p. 63)

My attention to educational landscapes of mathematics and science was enriched by two other writings. In The Golem: What Everyone Should Know About Science, Collins and Pinch (1993) succinctly encapsulate the very act of classroom teaching:

Every classroom in which children are conducting the same experiment in unison is a microcosm of frontier science. ... Think about what happens: the teacher asks the class to discover the boiling point of water by inserting a thermometer into a beaker and taking a reading when the water is steadily boiling. One thing is certain: almost no-one will get $100^{\circ} \mathrm{C}$ unless they already know the answer, and they are trying to please the teacher. Skip will get $102^{\circ} \mathrm{C}$, Tania will get $105^{\circ} \mathrm{C}$, Johnny will get $99.5^{\circ} \mathrm{C}$, Mary will get $100.2^{\circ} \mathrm{C}$, Zonker will get $54^{\circ} \mathrm{C}$, while Brian will not quite manage to get a result; Smudger will boil the beaker dry and burst the thermometer. Ten minutes before the end of the experiment the teacher will gather these scientific results and start the social engineering. ... That ten minutes renegotiation of what really happened is the important thing. ... These are theorists hovering around, like the school teacher, to explain and try to reconcile. ... There is nothing wrong with this; the only sin is not knowing that it is always thus. (pp. 150-151)

Collins and Pinch provide the confidence sometimes needed to continue with teaching, given that the chatter and noise in its conduct could become an issue with teachers from neighbouring classrooms. Not relegating practical issues of teaching in educational landscapes to the background, I now mention another text that introduced me to a dialectical approach in conducting science-one I come across once again by reading Vygotskian literature in my doctoral work. Promoting this view and in his chapter entitled, Not All in the Genes, evolutionary biologist Richard Lewontin (1997) argues against reductionist approaches in the pursuit of science and, as an example, points to the importance of the environment in the evolution of life on earth. Lewontin's views allowed me to more fully understand Darwin's theory of evolution and the concept 
of Vygotskian activity that I was to encounter later on. Lewontin also maintained that the answers one obtained in science depend to a large extent on the questions that were asked. The educational landscape of mathematics and science could thus be a nuanced one, and depended on the perspectives with which questions were conceived and formulated. I now turn to self-study of texts that shed light on the educational landscape in Sweden.

Unlike instructional landscapes in India which could vary from rote-driven learning environments to those which focused on creativity, even as multiple linguistic backgrounds of students were catered to, I found teaching in Sweden (which transpired in Swedish) to be more uniform in comparison. Yet, I embellish such cursory observations with my self-study of three texts that shed greater light on the country's unique educational landscape. The first text is from children's literature writer Astrid Lindgren, whose stories about playful Pippi's spirited and unpredictable antics are regular reading for most children. Not only did a student or two dress like Pippi at the schools I visited, but the sense of fun and frolic that Pippi inspired was also common across wider children's literature. In comparison, the tales that children traditionally grew up with in India were more steeped in folklore and mythology, though these too were "world making" and not without wit and wonder.

The second text, The Education of the Child, by Ellen Key (1910), predates Pippi by almost half a century. With her forthright style, Key drew specific attention to children's needs and their evolving personalities. She maintained,

The educator wants the child to be finished at once, and perfect. He forces upon the child an unnatural degree of self-mastery, a devotion to duty, a sense of honour, habits that adults get out of with astonishing rapidity. Where the faults of children are concerned, at home and in school, we strain at gnats, while children daily are obliged to swallow the camels of grown people.

Key addresses quite contemporary issues in schooling and research, with her candid as well as vehement opposition to competition among students in schools: "Every contest decided by examinations and prizes is ultimately an immoral method of training. It awakens only evil passions, envy and the impression of injustice on the one side, arrogance on the other." I mention Key in light of the widespread attention and subsequent frenzy created by cross-national comparative tests, both in Sweden and other countries worldwide. ${ }^{1}$ 
Echoing Key and speaking to citizenship issues of education at large, the final text I reflect upon allows me to highlight the spirit of social equality that I have found pursued with great intent in Sweden. My search for writings in English that shed light on this aspect led me to one which explained how John Dewey came to be an epistemic figure in Swedish discourse. It was in this text that I came across the concept of Folkhemmet or "people's homes" in Sweden, which for me seemed to be the basis for the egalitarian outlook being practiced in schools,

The foundation of The people's home [Folkhemmet] is fellowship and a spirit of togetherness. The good home is not acquainted with privileged or disadvantaged people, there are no favourites and no one is excluded. In the good home nobody looks down on anyone else, nobody tries to get advantages at someone else's expense, the strong do not oppress or exploit the meek. In the good home equality, consideration, cooperation and helpfulness prevail. (Olsson \& Petersson, 2005, p. 41)

In alluding to, however briefly, ideological and national concepts that embed different cultural and intellectual traditions, my objective has been to not only offer geographical and disciplinary flavour, but also consider how these aspects could formulate and guide practitioner thinking and action in the everyday of educational landscapes (Clandinin \& Connelly, 2007). I now turn to discuss my collaboration with another teacher-researcher.

\section{Teacher-Researcher Collaboration}

My engagement with Vygotskian perspectives in my doctoral work and initial conduct of interventions in Sweden brought me to three primary conclusions. First, if researchers wished to create productive learning environments in classrooms, they must work alongside teachers. Second, in working with teachers in their classrooms, researchers had to make efforts to overcome the deficit perspective that was held against teachers in individual and institutional ways. Finally, to conduct such studies, researchers needed to draw on frameworks which greater facilitated teacher-researcher collaboration. In keeping with these conclusions, I now outline my collaboration with a teacher named Lotta at her Grade 4-6 school.

My association with Lotta began when I sought to understand the teaching-learning dynamic in her grade six classroom. In a pilot study and as participant observer, I attempted to understand the narratives of her students as they learnt the mathematics 
that was expected of them. Speaking in situated ways of their experience with learning mathematics, I found students' narratives to satisfy the key feature of Vygotskian activity, that of simultaneously being a prerequisite and product (or tool and result) of any study. Drawing on narratives of Lotta and her students in this study, I observed that participant narratives had the potential to speak both of and for ongoing practice (Gade, 2010). Even as I anonymized Lotta as "Lea" in this writing, I made it a point to share my written work with her as it went through various drafts before publication. Contributing vitally to democratic as well as stakeholder validity, such actions enabled me as researcher to secure Lotta's trust as teacher. Over the summer holidays that followed, Lotta went on to obtain project funding for the topic entitled, "Mathematics and Communication," to be utilized with her new group of grade four students in the next year. It was projectrelated work during this academic year that sowed the seeds for the extended teacherresearcher collaboration discussed in this paper. The first example of such collaboration was when Lotta reported that she wanted to find a way to rectify her students' incorrect use of of the mathematical = sign. Accordingly, I used the theory of explicit mediation (Wertsch, 2007) to design and-with Lotta-jointly conduct a four-stage action cycle in response to the problem (Gade, 2012; Blomqvist \& Gade, 2013). While still referring to Lotta as Lea in reporting, our action research efforts enabled us to examine practical implementations and a theory of explicit mediation simultaneously as teacher and researcher. Moreover, such experiences emboldened us to design and conduct further classroom interventions. For example, we had Lotta's students make use of a specific category of talk designated as "exploratory" (Mercer \& Dawes, 2008) and examine their understanding of everyday measures (Gade, 2014). Conducting this intervention as a plenary, Lotta's students responded to improbable questions such as: "Can Eva and Anton measure the length of Sweden on foot?" and "Can Lars and Iris measure their age in decimetres?" In the course of our collaboration, this intervention was important in two ways. First, and at the outset, Lotta and I decided to analyze her plenary talk jointly, with the objective of co-authoring a journal article. Second, and as I shall soon discuss, I went on to unpack the very manner in which our collaboration developed over time.

Three frameworks help me flesh out teacher-researcher collaboration with Lotta, whose importance as a collaborative activity is advanced in this paper. Such a focus is sharpened by conceiving Lotta as researcher, her professional context as research site, and her instructional practice as the focus of our research (Cochran-Smith \& Donnell, 2006). Moreover, adopting this stance helps address the problematic theory/practice divide and overcome the deficit perspective held against teachers in the wider educational debate. This is done by recognizing their ability to deepen and enrich professional understanding through engagement with the ideas of others, in open conversations sustained by long-term relationships (Hollingsworth, Dybdahl, \& Minarik, 1993). 
Encapsulated by the term "relational knowing," the first framework I use alludes to the ability of teachers and researchers to relate to themselves, their students, and others as a primary manner of knowing. The second framework I draw upon recognizes the potential that exists when teachers and researchers talk with one another about the actions they take, as they collaborate on instruction in ongoing classrooms. Termed "cogenerative dialogue," such talk is also considered a more effective form of teacher preparation than just holding routine teacher workshops, wherein prescriptive examples offered to teachers may not be of use to them (Roth \& Tobin, 2004). Such dialogue is also a means with which to counter hegemonic tendencies of societal and institutional contradictions, which teachers face individually and risk internalizing in everyday schooling. My final framework has the potential to counter the false status of heroism that society tends to confer on teachers who work independently, often in isolation, and against all odds. The notion of "relational agency" counters this problem by recognizing the ability of teachers and researchers to work across institutional boundaries and pool resources towards shared goals they could jointly achieve (Edwards, 2010). Allowing teachers and researchers to collaborate across school and university confines, this notion recognizes the ability of both to reflect on joint instructional interventions. Exemplifying the use of each of these frameworks, I have discussed how Lotta and I drew upon each other and her students to exercise relational knowing in my pilot study (Gade, 2015). I also discuss how our intention to jointly analyze her plenary conduct and then co-author a journal article was an example of relational agency, as each of us pooled resources across our school and university. Finally, our joint analysis of the plenary talk was accompanied by co-generative dialogue in relation to our design, conduct, students' participation, and our afterthoughts. Even as I discuss yet another framework, that of an expansive learning activity (Engeström, 2001) with which to grasp my collaboration with Lotta in the concluding section of this paper, I now turn to reflect on insights from contemporary research on creativity and the nature of creative partnerships between people.

Contemporary research no longer views human creativity to be either a naturally driven process or personality based, but rather an activity which focuses on the generation of an end product that is novel, appropriate, useful, and valuable to a particular social group (Sawyer, 2011). This perspective allows me to consider teacher-researcher collaboration with Lotta to be a creative enterprise, wherein our design and conduct of classroom interventions were end products that were not only novel, but also very much deployable within ongoing instruction. Either with the $=$ sign or with exploratory talk, our interventions were activities that were not only instructionally useful, but also had direct educational value to Lotta, her students, and to me as researcher. 
I next turn to John-Steiner (2006), who discusses findings from extensive study of creative partnerships in art, literature, and the sciences. Evidencing how collaborating partners are sustained by the interest each other brings to a creative project, John-Steiner points to the delicate balance that is struck within partnerships with respect to individuality, interdependence, and mutual trust:

When individuals join together and build upon their complementarity in scientific disciplines, they expand their reach. The strength of these partnerships is as much in their common vision as in their complementary abilities. Collaboration offers partners an opportunity to transcend their individuality and to overcome the limitations of habit, and of biological and temporal constraints. (p. 57)

Both Sawyer and John-Steiner allow me to view my collaboration with Lotta as benefitting from the complimentarily that both of us brought to the table as teacher and researcher. By designing and conducting well-thought-out interventions, we were able to overcome the limitations Lotta faced in her individual capacity, one which I too faced in understanding how Vygotskian constructs played out in classroom scenarios. In parallel to the frameworks with which I understood our collaboration earlier on, John-Steiner's identification of four patterns of collaboration help to distinguish the roles, values, and working methods of participants, summarized in the table below.

\section{Table 1}

John-Steiner's Four Patterns of Collaboration

\begin{tabular}{|c|c|c|c|}
\hline PATTERNS & ROLES & VALUES & WORKING METHODS \\
\hline Integrative & Braided roles & $\begin{array}{l}\text { Visionary } \\
\text { commitment }\end{array}$ & $\begin{array}{l}\text { Transformative } \\
\text { co-construction }\end{array}$ \\
\hline Family & Fluidity of roles & $\begin{array}{l}\text { Common values } \\
\text { and trust }\end{array}$ & $\begin{array}{l}\text { Dynamic integration of } \\
\text { expertise }\end{array}$ \\
\hline Complementary & $\begin{array}{l}\text { Clear division of } \\
\text { labour }\end{array}$ & $\begin{array}{l}\text { Overlapping } \\
\text { values }\end{array}$ & $\begin{array}{l}\text { Discipline-based } \\
\text { approaches }\end{array}$ \\
\hline Distributed & $\begin{array}{l}\text { Informal and } \\
\text { voluntary }\end{array}$ & Similar interests & $\begin{array}{l}\text { Spontaneous and } \\
\text { responsive }\end{array}$ \\
\hline
\end{tabular}


Following John-Steiner and in relation to my pilot study, I found the nature of relationships between Lotta and me in that study to be spontaneous and responsive. At the time of this pilot our roles were informal and voluntary, making our collaboration distributed (see Table 1). Our subsequent conduct of classroom interventions was more complementary, based on shared values about the kind of interventions we wanted and went on to conduct. Our division of labour was clear, with Lotta conducting her plenary as teacher and me audio-recording her plenary talk as researcher. I next argue that our analysis of data for the purpose of co-authorship involved a fluidity of roles, for which we drew on mutual trust and exemplified a family pattern of collaboration. It was only when we pursued co-authorship in relation to Lotta's plenary talk (Gade \& Bomqvist, under review) that our collaboration took on a visionary commitment of empowering ourselves through research. Our roles in such attempts were braided and our methods transformative, leading to what John-Steiner identifies as an integrative pattern of collaboration. While not all forms of collaboration necessarily exhibit the four patterns identified by John-Steiner, taken together the category of patterns allows me to view how my extended collaboration with Lotta qualified the three human endeavors identified earlier in this article. In other words, our collaborative efforts were educative (for Lotta, her students, and me as researcher), scientific (in pursuing creative and imaginative ways), and democratic (involving each of us in the conduct of the study).

\section{Teacher Research: Conclusion}

I draw my arguments to a close by summarizing my combined experiences with teaching, self-study, and teacher-researcher collaboration. In doing so, I first single out the importance of understanding what Clandinin and Connelly (2007) call "educational landscapes." Whether in national contexts or in disciplinary contexts of mathematics and science, it is within these landscapes that practitioners think and take action in situated ways. As I have attempted to show, such thoughts and actions are not culture free but guided by these landscapes in non-deterministic ways. My own take on the importance of practitioner understanding of educational landscapes, exemplified in the form of my self-study, produced a narrative that embodies as well as provides a stimulus to an important and vital aspect in teacher research-that of practitioner agency. This characteristic is critical in understanding and advancing teacher research if professional contexts are to be research sites and instructional practices of teachers the focus of any educational research (Cochran-Smith \& Donnell, 2006). Not only is such agency critical to take part in the everyday conversations as put forth by Gadamer (Fairfield, 2010) but also in the democratic pursuit of science advanced by 
Bronowski (1965). Such human agency also plays a central role when practitioners seek truth or knowledge that is conducive to Buddhist well-being, on the one hand, and to Aristotelian good, on the other. Moreover, it was such agency that Lotta and I both drew upon and displayed, in bringing to fruition our teacher-researcher collaboration within her classroom and school.

The notion of expansive learning activity mentioned earlier on merits revisiting. Forwarded within a larger activity theory framework, this construct draws attention to human learning which is not merely reactive, but one that emerges as new forms of thinking and doing - in addition to being transformative in spirit within collaborative activity (Engeström, 2001). My collaboration with Lotta was an expansive learning activity, in which three frameworks enabled me to shed light on the moments which contributed to these forms of work and action (Gade, 2015). In proceeding from nascent beginnings of observing each other and building trust, we set our sights on co-authorship during the course of extended collaboration. In addition to practitioner self-study of one's own educational landscapes, I find such collaborative activity to be indispensable to teacher research. It is not difficult to identify such collaboration as being Vygotskian (1997), given that Lotta's students were active, Lotta and I were active, and the interventional environment that we forged between us was active as well. In such collaborative activity, Lotta and I were able to weigh practice and theory simultaneously, on even terms. Furthermore, there was also the potential to study the oft-perceived theory/practice divide, overcome the deficit perspective held against teachers, and redress its possible hegemonic effects. Taking such steps as practitioner and collaborating researcher enabled us to realize our own inquiry into Lotta's instruction as a stance for powerful and affirmative action (Cochran-Smith \& Lytle, 2009).

The environment we forged was not only a dynamic one, but also one in which we pursued knowledge that was vital to our advancement. Such collaborative activity is conducive for teacher research and much needed local action in schools. In sharing individual expertise across institutional boundaries, our solutions were both collective and creative. This collaboration also helped us broaden the very scope of educational research by asking questions that were pertinent to the settings in which the study bore fruit. It is towards these purposes and ends then, that I consider individual self-study and collaborative activity to be two sides of the same coin, simultaneously drawing upon and informing educational action in the everyday of educational landscapes. 


\section{Acknowledgment}

This article draws on collaborative research conducted with Charlotta Blomqvist, whom I call "Lotta" in my article. I discuss details of our extended teacher-researcher collaboration in Gade (2015) cited below.

\section{Notes}

1. A colleague in Sweden told me that the problem with such attention was that children from countries who do poorly on these tests are at risk of growing up and thinking they are just no good.

2. Vidyaranya High School for Boys and Girls

\section{References}

Blomqvist, C., \& Gade, S. (2013). Att kommunicera om likamedtecknet [Communicating about the equal to sign]. Nämnaren, 2013(4), 39-42.

Bronowski, J. (1965). Science and human values. New York: Harper and Row.

Bronowski, J. (1973). The ascent of man. London: British Broadcasting Corporation.

Clandinin, D.J., \& Connelly, F.M. (2007). Knowledge, narrative and self-study. In J Loughran et al. (Eds.) International Handbook of Self-Study of Teaching and Teacher Education Practices (pp. 575-600). Dordrecht: Springer.

Cochran-Smith, M., \& Donnell, K. (2006). Practitioner inquiry: Blurring the boundaries of research and practice. In J. L. Green, G. Camilli \& P. B. Elmore (Eds.), Handbook of complementary methods in education research (pp. 503-518). Mahwah, NJ: LEA.
Cochran-Smith, M., \& Lytle, S. (2009). Inquiry as stance: Practitioner research for the next generation. New York: Teachers College Press.

Collins, H., \& Pinch, T. (1993). The Golem: What everyone should know about science. Cambridge: Canto.

Edwards, A. (2010). Being an expert professional practitioner: The relational turn in expertise. Dordrecht: Springer.

Engeström, Y. (2001). Expansive learning at work: Toward an activity theoretical reconceptualization, Journal of Education and Work, 14(1), 133-156.

Fairfield, P. (2010). Education, dialogue and hermeneutics. London: Continuum International Publishing.

Gade, S. (Also G. Sharada) (2004). Creativity: Modern School Mathematics - A resource book for mathematics teachers. Hyderabad: Orient Blackswan/Longman. 
Gade, S. (2010). Narratives of students learning mathematics: Plurality of strategies and a strategy for practice? In C. Bergsten, E. Jablonka, \& T. Wedege (Eds.) Mathematics and Mathematics Education: Cultural and Social Dimensions. Proceedings of The Seventh Mathematics Education Research Seminar MADIF7 (pp. 102-112). Stockholm University.

Gade, S. (2012). Teacher researcher collaboration at a grade four mathematics classroom: Restoring equality to students usage of the ' $=$ ' sign. Educational Action Research, 20(4), 553-570. doi:10.1080/09650792.2012.727644

Gade, S. (2014). Practitioner collaboration at a Grade four mathematics classroom: By way of relational knowing and relational agency. In F. Rauch, A. Schuster, T. Stern, M. Pribila \& A. Townsend (Eds.), Promoting Change Through Action Research (pp. 35-47). Rotterdam, The Netherlands: Sense Publishers.

Gade, S. (2015). Unpacking teacher-researcher collaboration with three theoretical frameworks - a case of expansive learning activity? Cultural studies of science education. doi:10.1007/s11422-014-9619-7

Gade, S., \& Blomqvist, C. (under review). Investigating everyday measures through talk: Whole classroom intervention and landscape study at Grade four.

Hollingsworth, S., Dybdahl, M., \& Minarik, L. T. (1993). By chart and chance and passion: The importance of relational knowing in learning to teach. Curriculum Inquiry, 23(1), 5-35. doi:10.2307/1180216

John-Steiner, V. (2006). Creative collaboration. Cary, NC: Oxford University Press.
Key, E. (1910). The education of the child. The project Gutenberg ebook. Retrieved from: http://www.gutenberg.org/files/988/988.txt

Krishnamurti, J. (1929). Truth is a pathless land. Retrieved from: http://www.jkrishnamurti. org/index.php

Lewontin, R. (1997). Not all in the genes. In L. Wolpert \& A. Richards (Eds.) Passionate minds. The inner world of scientists. New York: Oxford University Press.

Mercer, N., \& Dawes, L. (2008). The value of exploratory talk. In N. Mercer and S. Hodgkinson (Eds.) Exploring talk in schools (pp. 55-71). London: Sage.

Olsson, U., \& Petersson, K. (2005). Dewey as an epistemic figure in the Swedish discourse on governing the self. In T. Popkewitz (Ed.) Inventing the modern self and John Dewey: Modernities and travelling of pragmatism in education (pp. 39-60) Palgrave: MacMillan.

Roth, W-M., \& Tobin, K. (2004). Coteaching: From praxis to theory. Teachers and Teaching: Theory and Practice, 10(2), 161-179.

Sawyer, K. (2011). Explaining creativity: The science of human innovation (2nd edition). Cary, NC: Oxford University Press.

Vygotsky, L. S. (1978). Mind in society: The development of higher psychological processes. Cambridge, MA: Harvard University Press.

Vygotsky, L. S. (1997). Educational psychology. Boca Raton, Florida: St. Lucie Press.

Wertsch, J. V. (2007). Mediation. In H. Daniels, M. Cole \& J. V. Wertsch (Eds.). The Cambridge Companion to Vygotsky (pp. 178-192). Cambridge: Cambridge University Press. 


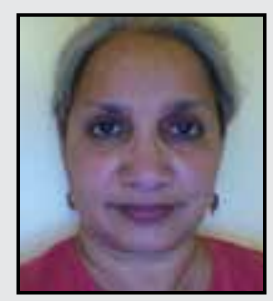

Sharada Gade is Assistant Professor in Mathematics Education at Umeå University. In collaboration with teachers largely at middle grades, she has conducted close-to-practice classroom research since 2008. Such work falls at the intersection of three research domains namely, CHAT perspectives, practitioner inquiry, and mathematics education. Subsequent to her doctoral work from Univesity of Agder, Norway, Sharada held visiting postdoctoral fellowships at Homi Bhabha Centre for Science Education (TIFR), Mumbai, India; Umeå Mathematics Education Research Centre, Umeå University, Sweden; The Graduate Centre, City University of New York, USA and Department of Education, University of Oxford, UK.

\section{LINK TO:}

http://www.ufm.umu.se/english/about-umerc/staff/view-person/.cid68430?uid=shg a0004\&guise $=$ employee 78686 